a collective action will be deemed to be commenced as to an individual claimant, not on the date the original complaint was filed, but on the date when the employee filed his written consent to become a party, ${ }^{68}$ the time lag between accrual of the cause of action and commencement of the collective action is increased, bringing more actions under the statute of limitations. The President, upon approving the Act, recognized an immediate need for additional appropriations to augment the inspection and enforcement program of the Wage and Hour Division ". . . . in order to detect violations early enough to protect workers from undue losses." ${ }^{\prime 69}$ To date no additional appropriations have been forthcoming.

Thus, despite the emergency nature of the Portal Act, a considerable revision of the Fair Labor Standards Act seems to have taken place. Although the Portal Act does appear to create greater certainty for employers, and does relieve them from the allegedly tremendous burden ${ }^{70}$ of portal to portal claims, it accomplishes this at the expense of limiting, and in some cases abolishing, the rights of workers established nine years before by the "remedial and humanitarian" Fair Labor Standards Act. It is to be regretted that, in an area as vital to the national economy as this, such major changes have been made under the guise of an emergency without thorough examination and consideration, and without the public scrutiny the situation demanded.

\title{
OVERLAPPING FEDERAL AND STATE REGULATION OF LABOR RELATIONS
}

Even those members of the Senate Committee on Labor and Public Welfare who opposed the passage of most parts of the Labor-Management Relations Act gave complete approval to Section ro(a), believing that the clarification of relations between the federal Board and state boards through the amendment of Section ro(a) of the National Labor Relations Act was a wise solution to a complex problem. ${ }^{x} \mathrm{~A}$ comparison of the two sections may be made plain by setting forth Section Io (a) of the NLRA, ${ }^{2}$ with that part which is omitted from

${ }^{68}$ Pub. L. No. 49, 8oth Cong. rst Sess., § 7(b) (May I4, I947).

69 H.R. Doc. No. 247 , 8oth Cong. Ist Sess. (r947).

${ }^{70} \mathrm{~A}$ strong case has been made to the effect that the portal-to-portal claims were not actually so financially staggering to the employers. Sugar, The Truth about "Portal to Portal," 7 Law. Guild Rev. 23 (I947); Smethurst and Haslam, "Portal-to-Portal" and Other Retroactive Liabilities, I5 Geo. Wash. L. Rev. I3I (I947). But cf, Cotter, Portal to Portal Pay, 33 Va. L. Rev. 44 (I947).

× Report of the Senate Committee on Labor and Public Welfare on S. II26, Senate Report I05, Part 2, 8oth Cong. rst Sess., at 4I (I947).

2 National Labor Relations Act § Io(a), 49 Stat. 453 (I935), 29 U.S.C.A. § I6o(a) (1947): act hereinafter referred to as NLRA. 
Section Io(a) of the LMRA ${ }^{3}$ in brackets, and with additions made by the LMRA in italics:

The Board is empowered, as hereinafter provided, to prevent any person from engaging in any unfair labor practice (listed in section 8 ) affecting commerce. This power shall [be exclusive and shall] not be affected by any other means of adjustment or prevention that has been or may be established by agreement, [code] law, or otherwise: Provided, That the Board is empowered by agreement with any agency of any State or Territory to cede to such agency jurisdiction over any cases in any indusiry (other thain mining, manufacturing, communications, and transportation except where predominantly local in character) even though such cases may involve labor disputes affecting commerce, unless the provision of the State or Territorial statute applicable to the determination of such cases by such agency is inconsistent with the corresponding provision of this act or has received a construction inconsistent therewith.

In providing that the National Labor Relations Board should have exclusive power to prevent unfair labor practices affecting commerce, Section ro(a) of the NLRA seemed unequivocal. Some of the states, however, soon after the passage of that Act began to exercise a power to act upon labor matters involving domestic corporations engaged in interstate commerce. The highest courts of New York and Wisconsin adopted the position that a state board and the national Board had concurrent jurisdiction. It was their belief that the states could regulate labor relations of any company in the state, even though involved in interstate commerce, until the national Board chose to act. ${ }^{4}$

The New York-Wisconsin concurrent jurisdiction view was not shaken by Allen-Bradley Co. v. Wisconsin Employment Relations Board, 5 the first case in which the United States Supreme Court considered the problem of conflict of jurisdiction between a state board and the national Board. In that case, although the union involved claimed that the company was subject to the jurisdiction of the national Board only, the state board felt it could decide the controversy since no prior action had been taken by the national Board. Upon investigation, the Wisconsin Board found that the union was engaged in mass picketing for the purpose of hindering the pursuit of lawful work, was threatening employees desiring to work with bodily injury, was obstructing entrance to and exit from the factory, was picketing the homes of employees, and was interfering with the free use of public streets surrounding the factory. The Board's

3 Labor Management Relations Act $\S 10(a)$, H.R. 3020, 80th Cong. Ist Sess. (Pub. L. No. IOI, I947); act hereinafter referred to as LMRA.

${ }_{4}^{4}$ "We discover nothing in the legislative history of the bill which later became the National Labor Relations Act to give comfort or support to the claim that Congress intended to exclude the states from the whole feld of labor relations so affecting interstate commerce as to warrant federal legislation." Wisconsin Labor Rel. Board v. Fred Rueping Leather Co., 228 Wis. 473, 488,279 N.W. 673,679 (1938). "We reach the conclusion, therefore, that the State Labor Relations Board may enforce the State act at least until such time as it is ousted by the exercise by the National Labor Relations Board of its jurisdiction under the National Act." Davega City Radio v. State Labor Rel. Board, 281 N.Y. I3, 24, 22 N.E. 2d r45, I49 (r939).

$s_{3}{ }_{5}$ U.S. 740 (r942). 
order to the union to cease and desist from those unfair practices was upheld by the Supreme Court of Wisconsin and then by the United States Supreme Court. Justice.Douglas, speaking for the Court, said, "The federal Act was not designed to preclude a State from enacting legislation limited to the prohibition or regulation of this type of employee or union activity..... Congress has not made such employee and union conduct as is involved in this case subject to regulation by the federal Board." Justice Douglas cautiously stated that his discussion was confined to the precise facts of the case and that no opinion was advanced concerning the validity of other types or orders in cases where the federal Board had not assumed jurisdiction. ${ }^{7}$ The holding was that state regulation of employee and union conduct not covered by the NLRA would not be condemned as an encroachment on the powers of the national Board. Although the New York-Wisconsin concurrent jurisdiction view was not denied in the AllenBradley case, nothing was said which would indicate that the United States Supreme Court approved that view.

One limitation on state regulation of labor relations was recognized by the Supreme Court in r945. In Bill v. Florida, ${ }^{8}$ the Attorney General of Florida sought to restrain a labor union and its business agent from operating within the state until they had complied with that section of a Florida statute which provided that no person should be granted a license to act as a business agent for a labor union who had not been a citizen and resident of the United States for ten years, who had been convicted of a felony, or who was not a person of good moral character. A fee of one dollar and a statement by officers of the labor union showing the applicant's authority had to accompany the application. A board, composed of the Governor, the Secretary of State, and the Superintendent of Education made final decisions on applications. 9 Justice Black stated that the Florida statute had been so construed and applied that the union and its selected representative were prohibited from functioning as collective bargaining agents except upon conditions fixed by Florida. ${ }^{\mathrm{r}}$ This section of the Florida statute was held repugnant to the NLRA because it resulted in a forfeiture of collective bargaining rights. Another section of the same statute, ${ }^{\mathrm{Ix}}$ requiring unions to file a report and pay a one-dollar annual fee, was also considered. This latter section was held-in and of itself-not to be in conflict with the national Act. But the use of an injunction for failure to comply with the requirements of the section was held to be an application of the law in a manner resulting in conflict with the NLRA, which, under the commerce clause, was supreme.

It was not until the case of Bethlehem Steel Co. v. New York State Labor Relations Board, ${ }^{12}$ decided April 7 , I947, that the United States Supreme Court was obliged to determine the validity of the New York-Wisconsin concurrent juris-

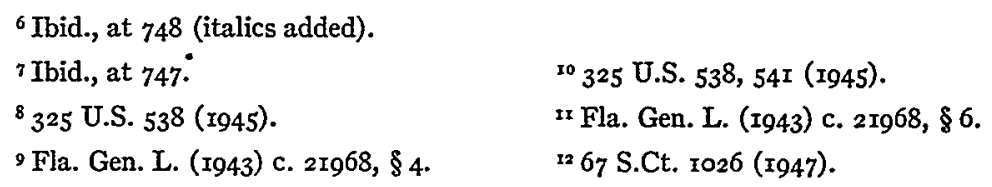


diction view. From May I943 until March 1945, the NLRB refused to hold that units of supervisory employees were appropriate for the purposes of collective bargaining within the meaning of Section 9 (b) of the NLRA..$^{x 3}$ During the same period, the New York State Labor Relations Board, acting under a state $\mathrm{Act}^{\mathrm{T}_{4}}$ nearly identical with the federal Act, recognized these units. The foremen of two large New York companies, being cognizant of the current policy of the national Board, filed petitions for certification with the state Board. Although the federal Board had previously determined that the two companies were subject to the NLRA and had certified representatives selected by various units of nonsupervisory employees at both plants, the state Board nevertheless assumed jurisdiction and was sustained in its action by the New York Court of Appeals..$^{15}$ On appeal to the United States Supreme Court it was held beyond the powers of the state of New York to follow a policy contrary to that of the NLRB with respect to the employee representatives of the two companies.

One aspect of the Bethlehem case has been nullified by Section 2(3) of the LMRA, ${ }^{16}$ which excludes any individual employed as a supervisor from the employee category. But questions of jurisdiction may yet arise under the LMRA, in which this equivocal case may be of decided importance. The Bethlehem Steel Company and the Allegheny Steel Corporation were clearly under the jurisdiction of the national Board. ${ }^{17}$ / Hence when foremen from the two cor-

13 In Matter of Maryland Drydock Company, 49 N.L.R.B. 733, 740 (1943), it was stated, "We are now persuaded that the benefits which supervisory employees might achieve through being certified as collective bargaining units would be outweighed not only by the dangers inherent in the commingling of management and employee functions, but also in its possible restrictive effect upon the organizational freedom of rank and file employees." This case was decided May II, I943, and from that date the Board repeatedly dismissed petitions for the establishment of bargaining units comprising supervisory employees. Matter of Boeing Aircraft, 5 I N.L.R.B.67 (1943); Matter of Murray Corporation of America, 5 I N.L.R.B. 94(r943); Matter of General Motors Corporation, 5I N.L.R.B. 457 (1943). Then on March 26, 1945, after the applications for certification in the Bethlehem action had been filed, the National Board indicated a change in policy, and asserted, ".... we find that all general foremen, foremen, assistant foremen, and special assignment men employed by the Company .... constitute a unit appropriate for the purposes of collective bargaining within the meaning of Section $9(\mathrm{~b})$ of the Act." Matter of Packard Motor Car Company, 6x N.L.R.B. 4, 26 (x945). See Collective Bargaining by Supervisory Employees under the Wagner Act, I3 Univ. Chi. L. Rev. 332 (1946).

The NLRA $\& 9$ (b), 49 Stat. 453 (1935), 29 U.S.C.A. $\&$ I59(b) (1947), stated "that the Board shall decide in each case whether, in order to insure to employees the full benefit of their right to self-organization and to collective bargaining .... the unit appropriate for the purposes of collective bargaining shall be the employer unit, craft unit, plant unit, or subdivision thereof." Compare LMRA $\S$ 9(b) H.R. 3020, 8oth Cong. Ist Sess. (Pub. L. No. xo1, 1947).

${ }^{14}$ N.Y. Labor Law (McKinney, I940) c. $30 \$ \S 700-716$.

${ }^{35} 295$ N.Y. 607,64 N.E. $2 d 352$ (I946).

${ }^{16}$ LMRA \& 2(3), H.R. 3020, 80th Cong. Ist Sess. (Pub. L. No. Ior, I947).

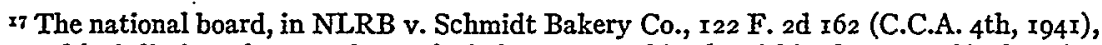
assumed jurisdiction where products of a bakery were sold only within the state of its location on the grounds that seventy-five per cent of the material used in the manufacture of its goods was shipped from outside the state. In Santa Cruz Fruit Packing Co. v. NLRB, $3^{\circ} 3$ U.S. 453 
porations sought certification by the state Board, the important issue presented was whether state action is precluded where the national Board concededly has jurisdiction but has not exercised it in the specific case.

The question was not to be answered by precedent. The action of the New York State Labor Relations Board could not be upheld on the basis of the AllenBradley case, for, to come within the rule of that case, the employee and union conduct must not have been covered by the NLRA. Since the NLRA provided for investigation by the national Board whenever a question affecting commerce arose concerning the representation of employees, ${ }^{18}$ the conduct in question was regulated. On the other hand, the action of the state Board could not be condemned on the basis of $B$ ill v. Florida, for interference with collective bargaining would have to be shown if the rule of that case were to be invoked. In the Bethlehem case, collective bargaining was facilitated when the New York Board certified a bargaining unit which would not have been certified (at that time) by the national Board.

Justice Jackson, speaking for the majority, began by stating that the initial question was whether, Congress having undertaken to deal with the labor relationship here involved, the states could not do so. Congress had not laid down any guides for the construction of the Act, and it was therefore necessary to consider the relation of federal and state power to the subject matter of the case to determine whether exclusion of state authority could be implied. The Court found that the subject matter was not so blended with national government responsibilities that its nature alone raised an inference of exclusion.

After apparently holding that the Act did not exclude state authority, the Court stated that states may, under regulative statutes such as the NLRA where effective regulation awaits the issuance of rules by an administrative body, exercise their police power in the interval before those rules are established.

\section{However,}

.... the conclusion must be otherwise where failure of the federal officials affirmatively to exercise their full authority takes on the character of a ruling that no such regulation is appropriate or approved pursuant to the statute.... It is clear that the failure of the National Labor Relations Board to entertain foremen's petitions was of the latter class. ${ }^{19}$

(1938), the cannery involved obtained all.of its fruits and vegetables locally, but the national board took jurisdiction because substantial quantities of the cannery's products were shipped in interstate and foreign commerce. Most of the products of the two subject corporations were shipped to points outside the state of New York, and most of the raw materials delivered to the plants from out-of-state. Briefs of United States (I946) Nos. 55, 76 and I2 and 16 ; see also Consolidated Edison Co. v. NLRB, 305 U.S. 197, 222 (1938).

$$
\begin{aligned}
& { }^{8} \text { NLRA } \S 9 \text { (c), } 49 \text { Stat. } 453 \text { (1935), } 29 \text { U.S.C.A. } \$ \text { Y59 (c) (1947). } \\
& { }^{19} 67 \text { S.Ct. 1026, 1030 (1947). }
\end{aligned}
$$


Justice Jackson declared that a different problem not here decided would arise if the reason for the national Board's refusal to take jurisdiction was not a matter of policy, but was "for budgetary or other reasons."

The opinion is not entirely free from ambiguity. While the Court suggested that the Act itself did not oust state jurisdiction, there is other language which throws some doubt upon the conclusion that it was the policy of the Board and not the NLRA itself which prevented the exercise of jurisdiction by the state Board. The following paragraph is an example:

The federal board has jurisdiction of the industry. . . . It asserts, and rightfully so, under our decision in the Packard case, ${ }^{2 x}$ its power to decide whether these foremen may constitute themselves as a bargaining unit. We do not believe this leaves room for the operation of the state authority asserted.2.

This statement has been interpreted as an assertion that the mere fact that the national Board has power to act is sufficient to exclude state action. Justice Frankfurter, dissenting, believed that:

the Court's opinion carries at least overtones of meaning that, regardless of the consent of the National Board, New York is excluded from enforcing rights of collective bargaining in all industries within its borders as to which Congress has granted opportunity to invoke authority of the National Board..$^{23}$

Justice Frankfurter was convinced that the majority opinion put an end to the convenient cooperative agreements between the national and state boards, and, although the majority had not committed itself as to cases where budgetary or other reasons were the cause of Board inaction, he was "unable to see how state authority [could] revive because Congress [might'see] fit to put the Board on short rations." ${ }^{24}$

It must be remembered that the Court was concerned with representation, and not unfair labor practices, in the Bethlehem case. Hence Sections 9(b) and 9(c) of the NLRA were involved, and not Section Io(a). Section 9(c) provided for investigation by the national Board "whenever a question affecting commerce arises concerning the representation of employees. . . .." ${ }_{25}$ No words of

20 Ibid., at ro3r (1947).

${ }^{22}$ Matter of Packard Motor Car Company, 6r N.L.R.B. 4 (r945).

2267 S.Ct. I026, 103I (x947). ${ }_{23}$ Ibid., at ro32.

24 Ibid., at ro33. About a month after the Bethlehem case, Justice Douglas cited it as authority for the statement that "We recently noted that Congress can act so unequivocally as to make clear that it intends no regulation except its own." Rice v. Santa Fe Elevator Corp., 67 S.Ct. II46, II55 (1947).

${ }_{25}$ NLLRA $\S 9$ (c), 49 Stat. 453 (x935), 29 U.S.C.A. $\S$ I59(c) (1947). These words have not been appreciably changed by $\$ 9$ (c) of the LMRA, H.R. 3020, 8 oth Cong. Ist Sess. (Pub. L. No. IOr, I947): “. . . if it [national Board] has reasonable cause to believe that a question of representation affecting commerce exists it shall provide for an appropriate hearing upon due notice."

"The term 'affecting commerce' means in commerce, or burdening or obstructing commerce or the free flow of commerce, or having led or tending to lead to a labor dispute burdening or 
sole power to handle representation cases appeared in the NLRA or now appear in the LMRA. It thus seems reasonable to conjecture that if, as Justice Frankfurter supposed, the decision of the Court meant that the national Board's jurisdiction under the NLRA was exclusive in representation cases, then, a fortiori, the Court would also feel it was exclusive in unfair labor practice cases where the applicable Section, Io(a), included an express provision to that effect.

While it appears that the concurrent jurisdiction view could perhaps be considered abated by the Bethlehem decision, the Supreme Court of Wisconsin did not submit to such an interpretation. It is not surprising that the Wisconsin Court, two months afterwards, was still saying, "The National Labor Relations Board not having exercised any jurisdiction of such labor dispute the State Board may exercise jurisdiction of it." ${ }^{26}$ Although the company involved in the case was within the jurisdiction of the national Board, and although the $\mathrm{Na}$ tional Labor Relations Board had certified the union as the bargaining agent of the employees, the Wisconsin Court stated that the Bethlehem case did not apply. That court interpreted the Bethlehem case as a holding that when the national Board declined to designate foremen as a bargaining unit it was exercising the jurisdiction delegated to it under the federal Act, thus excluding state regulation. ${ }^{27}$

The Pennsylvania Supreme Court took, like Justice Frankfurter, a broader view of the intended impact of the Bethlehem case. In Pittsburgh Rys. Co. Substation Operators and Maintenance Employees ${ }^{\prime}$ Case, $^{28}$ that Court averred that the clear implication of the decision is that wherever Congress has the power of regulation over the employer-employee relationship and has acted with regard to that relationship, state power is suspended and cannot constitutionally be exercised.

The latter interpretation, prior to the passage of the LMRA, appeared unfortunate in at least one respect. The National Labor Relations Board cannot dispose of all cases coming within its constitutional power. Budgetary limitations have in the past hampered the Board, ${ }^{29}$ and at times there might be such a backlog of cases that prompt hearing would be impossible. ${ }^{30} \mathrm{It}$ is apparent

obstructing commerce or the free flow of commerce." NLRA $\S 2$ (7), 49 Stat. 450 (I935), 29 U.S.C.A. $\S 15^{2}$ (7) (1947). LMRA § 2 (7), H.R. 3020 8oth Cong. rst Sess. (Pub. L. No. Ior, I947).

${ }^{26}$ International Union v. Wisconsin Employment Rel. Board, 27 N.W. $2 \mathrm{~d} 875,883$ (Wis., I947).

${ }^{27}$ Tbid. Perhaps the International Union case could be justified on the basis of the AllenBradley case. This would require a showing that the NLRA did not cover the union activity involved in the case.

${ }^{28} 54$ A. 2 d 89x, 895 (Pa., I947).

${ }^{29}$ U.S. Briefs (1946) Nos. 55, 76 at p. 67.

${ }^{30}$ At the end of 1946 , the board had 460 unfinished cases. Bethlehem Steel Co. v. New York Labor Rel. Board, 67 S.Ct. 1026, 1035 (1947). 
that if the fact that the, national Board has jurisdiction is sufficient to prevent the exercise of state jurisdiction, and if the federal Board is unable to dispose of all cases over which it has jurisdiction, some employer-employee disputes will not receive a hearing. Congress has attempted to remedy the situation in Section Io(a) of the recent Act by empowering the national Board to cede jurisdiction to state agencies..$^{3 x}$ There seems implicit in the section a recognition of the Frankfurter-Pennsylvania interpretation of the Bethlehem case, for unless the states have no authority in cases affecting commerce until given it by the NLRB, the provision for ceding jurisdiction is of no use. A condition precedent to a cession of jurisdiction is that the statute under which the state board operates must be consistent with the corresponding provision of the federal Act and must not have received a construction inconsistent therewith. ${ }^{32}$ This makes employer-employee protection, in some cases, depend upon whether the state in question has a statute consistent with the corresponding section of the LMRA. It appears that Section Io(a) will encourage state legislation consistent with the national Act. The states have their choice between passing such legislation and construing it in a manner consistent with the national Board's construction of the federal Act, or taking no part in regulating unfair practices which affect commerce.

Two other sections of the LMRA have sufficient effect upon federal-state relations to deserve consideration along with Section ro(a). Section $\mathrm{r}_{4}(\mathrm{a})^{33}$ provides that no employer subject to the LMRA shall be compelled to deem individuals defined as supervisors as employees for the purpose of any law relating to collective bargaining. The section narrows the effect of the Allen-Bradley decision by prohibiting states from giving supervisors collective bargaining rights-even in the absence of federal regulation.

Section $\mathrm{I}_{4}(\mathrm{~b})^{34}$ makes it clear that the LMRA does not authorize union shop agreements under Section 8(a) (3) in states where the union shop, preferential hiring, or any agreements requiring membership in a labor organization as a condition of employment are prohibited by state law. A state is free to act under this section providing its regulations are at least as stringent as those of the national Board, and the action may be taken without any cession from the national Board. Nearly one-third of the states have already declared closed shop agreements unlawful. ${ }^{35}$

${ }^{31}$ LMRA § ro(a), H.R. 3020, 8oth Cong. 1st Sess. (Pub. L. No. Ior, 1947).

${ }^{3}$ Ibid.

${ }^{33}$ LMRA § I4(a), H.R. 3020, 80th Cong. Ist Sess. (Pub. L. No. Ior, I947).

34 Ibid., at $\$ \mathrm{I}_{4}(\mathrm{~b})$.

35 Ariz. L. (I947) c. 81; Ark. Acts (1947) c. ror; Del. Laws (1947) c. I96; § 30; Fla. Const. Declaration of Rights, \$ I2; Ga. L. (1947) Act. No. 140; Iowa Acts (1947) c. 296; La. Gen. Stat. Ann. (Dart. 1939) §65; Neb. Const. Art. $x_{5} \$ \S$ I3 $_{3}-15$; N.C. L. (1947) c. 328; S.D. L. (1947) S.B. 224; Tenn. Pub. Acts (1947) S.B. 367; Tex. Ann. Rev. Civ. St. (Vernon, 1947) art. 5207a; Va. Acts (I947) c. 2 § I-8. These provisions all seem to include union shop as well as closed shop agreements. 
Section Io(a), together with Sections $\mathrm{I}_{4}(\mathrm{a})$ and $\mathrm{I}_{4}(\mathrm{~b})$, indicates that Congress intends the national Board to have control over labor relations affecting commerce unhampered by state legislatures or state boards. If the Bethelehem case is to be construed as an absolute prohibition on state regulation, state boards may claim authority to act only when jurisdiction is ceded by the national Board. The national Board will yield jurisdiction only where the state statutes are compatible with the federal Act, and where the state act has been given a congenial construction./

There is another possibility-one which would take the exclusive control over all labor relations out of the hands of the NLRB and allow the exercise of state jurisdiction, even where not ceded by the national Board. It is reasonable to suppose that Justice Jackson did not intend to bar the states except where they were following a policy contrary to that of the national Board. The Wisconsin Supreme Court believed that the Bethlehem opinion went no further. ${ }^{36}$ If it did not, there is no reason why states cannot exert jurisdiction over labor disputes in cases affecting commerce without receiving the sanction of the NLRB, as long as they are not following a policy opposed to that of the federal Board. For while the LMRA does empower the NLRB to cede jurisdiction to state boards, it does not explicitly make the power of the Board exclusive.

It therefore becomes clear that Section IO(a) of the LMRA has not clearly defined the respective scopes of jurisdiction of the national and state boards unless buttressed by one of two possible interpretations of the Bethlehem case. Until the Supreme Court undertakes to clarify the meaning of that decision, the problem of jurisdictional conflicts will remain unsettled.

${ }^{36}$ International Union v. Wisconsin Employment Rel. Board, 27 N.W. 2d 875, 883 (Wis., 1947). 